DOI: https://doi.org/10.31933/dijdbm.v2i2 Received: 28 November 2020, Revised: 20 December 2020, Publish: 3 March 2021

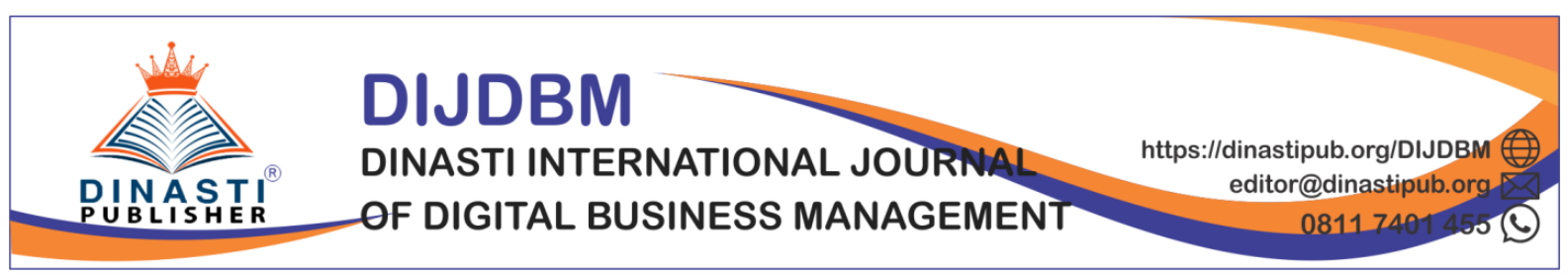

\title{
PERFORMANCE MODEL OF HEALTH WORKER AT THE JOHAR BARU DISTRICT HEALTH CENTER
}

\author{
Handy Suryadi ${ }^{1}$, M. Havidz Aima ${ }^{2}$, Hernawati W. ${ }^{3}$. Wiratih Wiratih ${ }^{4}$, Siti Rohmawati $^{5}$, \\ Ngadino Surip ${ }^{6}$ \\ ${ }^{11}$ Master of Management, Mercu Buana University, dr.handy.suryadi@gmail.com \\ ${ }^{2)}$ Master of Management, Mercu Buana University, havidz.aima@mercubuana.ac.id \\ ${ }^{3)}$ Master of Management, Mercu Buana University, hernawati_life@yahoo.com \\ ${ }^{4)}$ Master of Management, Mercu Buana University \\ ${ }^{5)}$ Master of Management, Mercu Buana University, sitirohmawati286@gmail.com, \\ ${ }^{6}$ Master of Management, Mercu Buana University, dinosurip@gmail.com
}

Corresponding Author: Handy Suryadi ${ }^{1}$

\begin{abstract}
The aim of this study is to identify and explain the influence of culture and training on organizational commitment and its effect on the performance of employees at the District Health Center Johar Baru, Central Jakarta. The research method in this study uses a a causality quantitative approach. The population is all health workers at the Johar Baru Puskesmas with probability sampling techniques and simple random sampling techniques. The data obtained were analyzed using structural equation modeling (SEM) with the Smart PLS version 3.2.8 software program. The results of this study indicate that organizational culture, training and organizational commitment have a significant positive effect on employee performance partially or simultaneously. In addition, organizational commitment mediates organizational culture and performance training. Research suggestions in the aspect of managing performance targets should be arranged in quality and quantity by considering "people"As executor of activities. Leadership decision making must combine all constructive ideas and opinions, employee selection to determine training priorities so that it is right on target which can be done concretely through leadership training, capacity building, routine motivation programs, evaluation, reward and punishment.
\end{abstract}

Keyword : Organizational Culture, Training, Organizational Commitment and Employee Performance.

\section{INTRODUCTION}

Puskesmas performance appraisal is an effort to assess the work results or performance of the puskesmas which are projected from each performance of the Health Worker in it. Health worker performance appraisal is intended to measure the level of achievement of its employees so that the puskesmas can always maintain quality and competitive human resources in order to create public health services according to the expectations of the community which in turn lead to satisfaction in using puskesmas services. Puskesmas Johar Baru is the First Level Health Facility that serves people who take part in 
achieving the vision of a healthy Indonesia 2025. The positive achievements of Puskesmas Johar Baru depend on the management of Human Resources for Health to run the puskesmas work program. Because humans are the most important asset in an organization whose capacity can be improved continuously in their work.

Each puskesmas has 2 (two) main areas of service, namely individual health care services and public health service providers, as well as the Johar Baru Puskesmas. Individual health care services are individual health services consisting of prevention and treatment services for individuals who are sick. Public health services provided by the puskesmas are oriented towards public health with the target family, community groups in the working area of the puskesmas. In their accountability to the health office, the puskesmas must meet the Minimum Service Standards on individual and community health that can be achieved by health staff in the puskesmas.

The performance achievement of Puskesmas Johar Baru in the two health services provided was carried out by PNS and non PNS health officials. In the performance of employees at the Johar Baru Subdistrict Health Center in 2018, there were still employees who had performance below the "good" standard and this had increased by 3 (three) people in each health unit, and there was an increase of $6.18 \%$ in the last two years. In 2016, the Johar Baru Puskesmas achieved a performance of 90.9\%, the following year in 2017 there was an increase in achievement of $91.53 \%$ then there was a deviation in the achievement of the following year to $85.03 \%$. The performance target set by the Johar Baru Subdistrict Health Center is $100 \%$, which means that the Healthcare Worker of the Johar Baru Puskesmas must have all performance in the "good" category, but in the last three years the Puskesmas performance target has not been realized because there are still employees whose performance under the "good" category.

From the researcher's analysis, the things that influence the increase and decrease of an employee's performance are organizational culture (67\%), organizational commitment $(60 \%)$, and employee training (67\%). Based on the problems found in the Johar Baru District Health Center, the researchers wanted to raise the theme of "Performance Models of Health Worker at the Johar Baru Health Center".

\section{Research Objectives and Statements}

The purpose of this study was to develop a model to measure decisions in the development of organizational culture and training in getting the best performance of employees through organizational commitment mediation. This research includes the following theoretical objectives :

1. Introducing employee performance treatment decision models .

2. To determine the relationship between organizational culture and training on employee performance through organizational commitment mediation

3. To find out and measure several indicators related to organizational culture, training, employee performance and organizational commitment

Based on the above purpose, research define formulation of the question as follows:

1. Does organizational culture have a significant effect on organizational commitment?

2. Does training have a significant effect on organizational commitment?

3. Does organizational culture have a significant effect on employee performance? 
4. Does training have a significant effect on employee performance?

5. Does organizational commitment have a significant effect on employee performance?

6. Does the organizational culture and training together have a significant effect on organizational commitment?

7. Does the organizational culture, training and organizational commitment have a significant effect in air equally to employee performance?

8. Does organizational commitment significantly mediate organizational culture and training on employee performance?

\section{LITERATURE REVIEW Organizational Culture}

Irham Fahmi (2016: 185) mentions organizational culture as a system that has been in process for a long time in the organization, then it is applied in various work activities and becomes an encouragement to add value to the work performance of employees from the top position to the lowest position. Robbins and Judge (2013: 512) state that organizational culture is a paradigm that is carried out simultaneously by all individuals in an organization that describes the specific uniqueness of an institution. Wibowo (2017: 74) explains elements of organizational culture, namely paradigms, norms and forms of governance. The various views of these experts can be concluded that organizational culture is a common belief, appearance and measure to foster employees in acting in order to achieve institutional goals.

\section{Training}

Labor regulations state that training is intended to improve workers' skills. Law of the Republic of Indonesia Number 13/2003 regarding manpower, explains that training is carried out in order to expand capacity, develop, improve work quality according to position and job qualifications, including discipline, attitudes and a good work culture. According to Sumarsono (2009) in Sinambella (2018: 169 ) training is a form of investment provided by the budget to expand the level of work expertise of employees. Noe (2013) argues in Kasmir (2016: 126) that the training provided by the organization is a facility to increase work activities related to the insights, skills and attitudes of employees. So that through preplanned training by the organization it can improve employee knowledge, skills and behavior..

\section{Organizational Commitment}

Commitment is a bond between the organization and the workers, the commitment within the organization to characterize the relationship of workers to organizational implications will be an effect on the worker whether to remain in the organization's environment or not. Meyer and Allen in Luthans (2011: 148), describes three dimensions of organizational commitment, namely affective commitment, continuity commitment and normative commitment. Affective commitment describes how deeply an employee is emotionally bound, recognizes and involved in the organization. Continuity commitment is the desire of employees, based on the employee's perception of the losses he will face if he leaves the company, so that employees feel the need to be connected with the company. This normative commitment is related to having a sense of belonging, being happy, comfortable, proud which leads to loyalty to carry out the job obligations given to the organization. According to Colquitt et al (2015) in Ricardianto (2018: 176), what is meant by organizational commitment is a person's desire to work and remain part of the organization. Wibowo (2017: 431) concludes organizational 
commitment represents the attitude and behavior of employees to identify themselves as part of the self involvement, high faithfull attitudes in reaching the organization target. According to Indra Kharis (2015), organizational commitment is a condition for someone to take sides and want to maintain membership in the organization.

\section{Employee Performance}

Performance is defined as an individual's success in carrying out the task, the work and responsibility of the tasks assigned and the quantity, quality and time in carrying out the task. According Mangkunagara (2015: 67) the employee's performance is a work based on the target number and weight of the work achieved by the employee in performing his task responsibilities. According to Armstrong and Baron (1998) in Wibowo (2017: 7) states that the performance associated with the strategic objectives of the organization, satisfaction of customers and have an influence on the value of the economy. According to Lestari (2016), performance is something that someone shows regarding a predetermined work task including input, process, output results obtained from work activities.

\section{Research model and hypotheses Research Model}

From the above explanation, the research model developed in this journal is as shown in Figure 1. Organizational culture and training as a independent variable will affect Commitments as a mediating variable. In addition, the Organizational Culture and Training will affect the performance of employees as the dependent variable. Figure 1 below provides an overview of the research model.

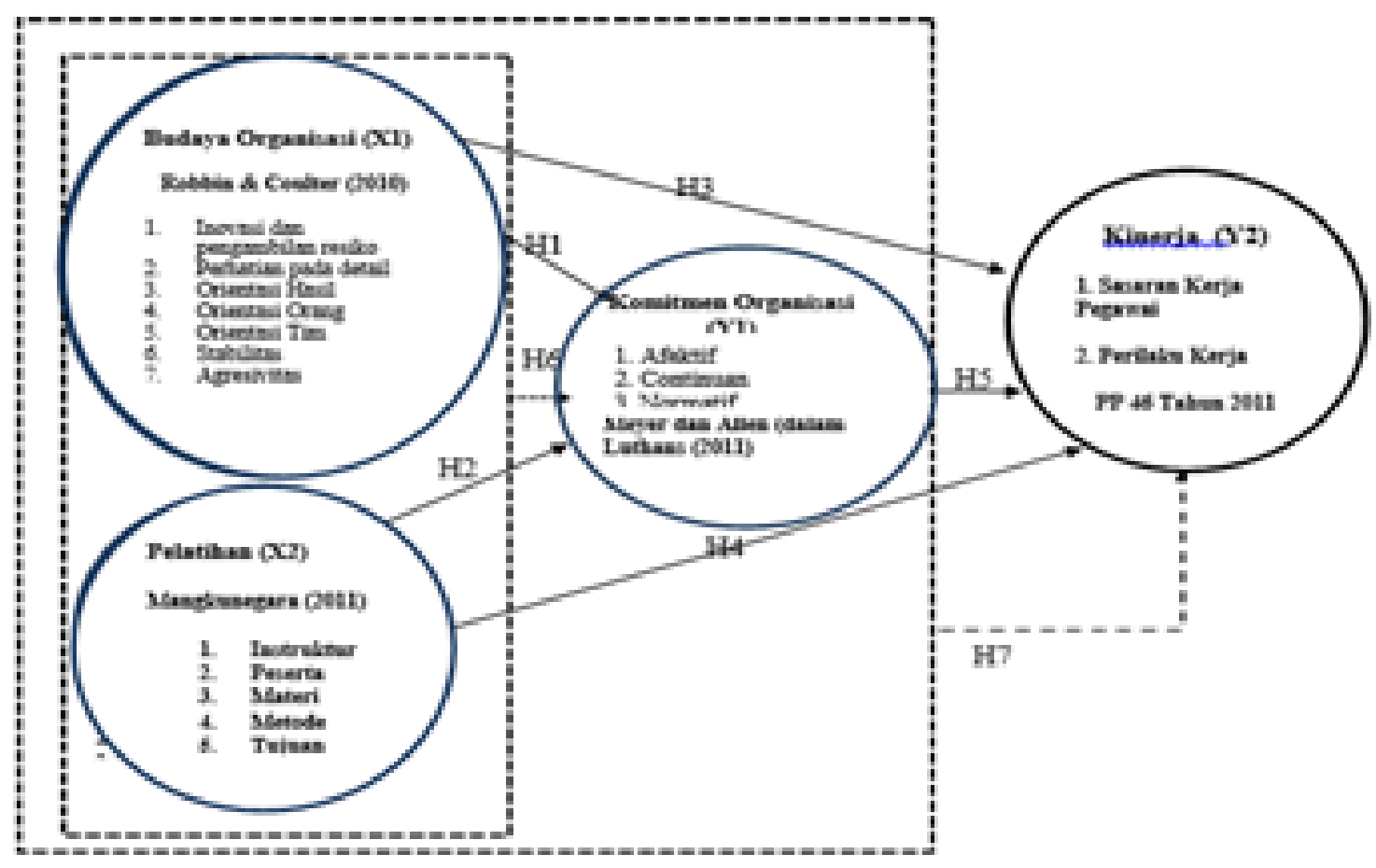

Figure 1. Framework Model 


\section{Hypothesis}

Based on the literature review and the framework described above, the proposed hypothesis is as follows:

H1: Organizational culture has a significant effect on organizational commitment.

H2: Training has a significant effect on organizational commitment.

H3: Organizational culture has a significant effect on employee performance.

H4: Training has a significant effect on employee performance.

H5: Organizational commitment has a.significant effect on employee performance.

H6: Organizational culture and training together have a significant effect on organizational commitment.

H7: organizational culture, training and organizational commitment jointly have a significant effect on employee performance

H8: Organizational commitment.significantly mediates organizational culture and training on employee performance.

\section{Methodology}

The research model is using a kind of quantitative statistical analysis survey method in order to understand, explain and analyze the relationship between the independent variables (exogenous) that organizational culture (X1) and training (X2) with the dependent variable (endogenous variables) that organizational commitment (Y1 ) and employee performance (Y2) . This type of research is research using descriptive quantitative methods .

The quantitative method is carried out by submitting questionnaires to respondents who are assigned. The stages of research are pre- survey activities, survey research model formation, confirmatory research, and data analysis (Neuman, 2006). The pre-survey was carried out by distributing questionnaires containing closed questions to 30 health workers at the Johar Baru District Health Center. Furthermore, research have been done by distributing questionnaire to respondents using a Likert scale to 120 health officials health worker are set. Respondents were obtained by taking a sample of the overall officials health worker population who totaled 170 person ( a hundred and seventy ) people based on employment data in October 2018. The technique of taking probability sample by simple random sampling (slovin $5 \%$ error tolerance).

This study uses the Partial Least Square (PLS) analysis technique using the SmartPLS software which is run on computer media. PLS (Partial Least Square) is a variant-based Structural Equation Model (SEM) analysis that can simultaneously perform measurement model testing and structural model testing. The measurement model is used to test the validity and reliability, while the structural model is used for the causality test, hypothesis testing with a predictive model (Ghozali , 2016) . 


\section{RESULT AND DISCUSSION}

This research was conducted through analysis of measurement models first to see its validity and reliability, then followed by structural model analysis

\section{Analysis of the outer model (measurement model)}

This analysis was conducted to see the validity and reliability of indicators used to measure a variable latent. In the analysis of this table previously conducted by convergent

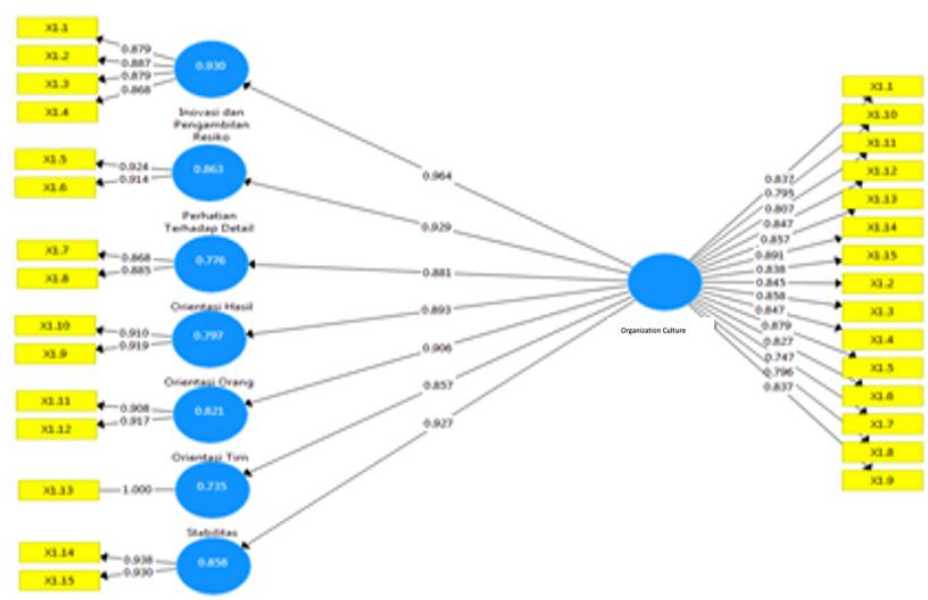

test validity. Furthermore, the analysis conducted by discriminant test validity . To test the validity of indicators, value loading factors $>0.7$ is declared as a valid and used indicator. The results of this study are shown in Figure 2- Figure 5 .

Figure 2. Calculation Results of the Measurement Model (Outer Model) of Organization Culture Variables Source : Smart PLS Version 3.2.8

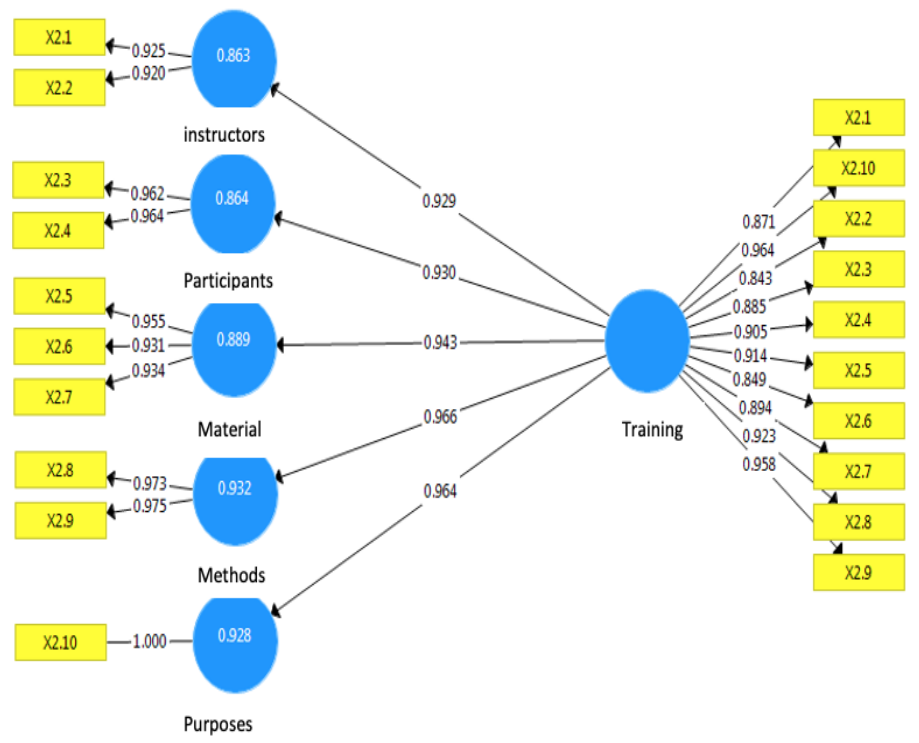

Figure 3. Calculation Results of the Measurement Model (Outer Model) of Training Variables 


\section{Source : Smart PLS Version 3.2.8}

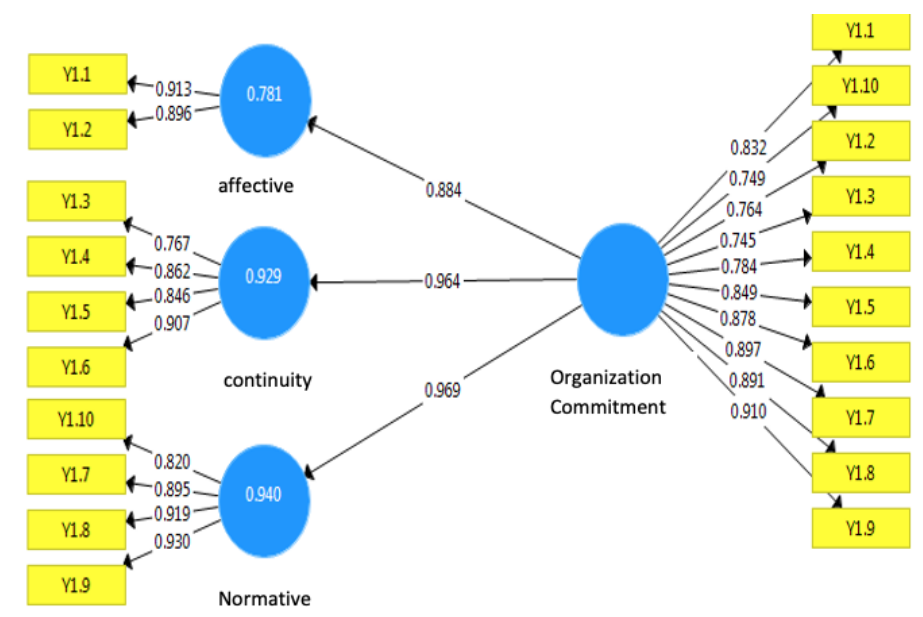

Figure 4. Calculation Results of the Measurement Model (Outer Model) of Organizational Commitment Variables

Source : Smart PLS Version 3.2.8

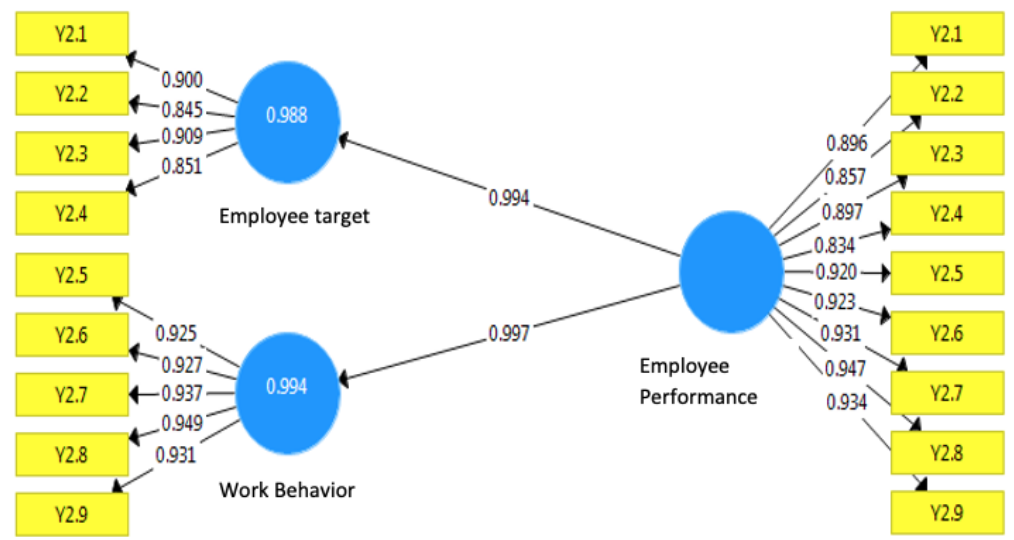

Figure 5. Calculation Results of the Measurement Model (Outer Model) of Employee Performance Variables Source : Smart PLS Version 3.2.8

The results of convergent validity with SmartPLS version 3.2.8 are shown in Figure 2 to Figure 5. It can be seen that the indicators on the variables of organizational culture, training, organizational commitment and employee performance show the loading factor value $>0.7$, it means. the indicators are valid and can be used in the model.

Table 1.Result of Cronbach's Coefficient Alpha and Composite Reliability Test (CR)

\begin{tabular}{lccccc}
\hline \multicolumn{1}{c}{ Variable } & $\begin{array}{c}\text { Composite } \\
\text { Reliability }\end{array}$ & Requirement & $\begin{array}{c}\text { Cronbach's } \\
\text { Alpha }\end{array}$ & Requirement & Result \\
\hline Organizational Culture $\left(\mathrm{X}_{1}\right)$ & 0.972 & $>0,7$ & 0.969 & $>0,6$ & Reliable \\
\hline Training $\left(\mathrm{X}_{2}\right)$ & 0.977 & $>0,7$ & 0.974 & $>0,6$ & Reliable \\
\hline $\begin{array}{l}\text { Organizational Commitment } \\
\left(\mathrm{Y}_{1}\right)\end{array}$ & 0.957 & $>0,7$ & 0.950 & $>0,6$ & Reliable \\
\hline Employee Performance $\left(\mathrm{Y}_{2}\right)$ & 0.976 & $>0,7$ & 0.972 & $>0,6$ & Reliable \\
\hline \multicolumn{2}{c}{ Source: Smart PLS versi 3.2.8 }
\end{tabular}


Table 1 shows that the Cronbach's Coefficient Alpha value on the variables of organizational culture, training, organizational commitment and performance> 0.6 or close to 1 and the value of Composite Reliability $(\mathrm{CR})>0.7$, then all variables are declared reliable.

\section{Analysis of the inner model (sctructural model )}

Evaluation of the path coefficient value based on the calculation results using calculate SmartPLS version 3.2.8 bootstrapping is to produce a path coefficient that describes the strength of the relationship between constructs/variables according to table 2 and Figure 6 below.

Table 2.Result of Path Coefficient Test

\begin{tabular}{|c|c|c|c|c|c|}
\hline & $\begin{array}{c}\text { Origin } \\
\text { Sample } \\
\text { (O) }\end{array}$ & $\begin{array}{c}\text { Mean } \\
\text { Sample } \\
(\mathbf{M}) \\
\end{array}$ & $\begin{array}{l}\text { Standard } \\
\text { Deviation } \\
\text { (STDEV) } \\
\end{array}$ & $\begin{array}{c}\text { T Statistic } \\
\text { (O/STDEV) }\end{array}$ & P Values \\
\hline $\begin{array}{l}\text { Organizational Culture (x1) -> } \\
\text { Organizational Commitment } \\
\text { (y1) }\end{array}$ & 0.458 & 0.454 & 0.071 & 6.454 & 0.000 \\
\hline $\begin{array}{l}\text { Organizational Culture }(\mathrm{x} 1)> \\
\text { Employee Performance }(\mathrm{y} 2)\end{array}$ & 0.154 & 0.159 & 0.063 & 2.449 & 0.015 \\
\hline $\begin{array}{l}\text { Training (x2) -> } \\
\text { Organizational Commitment } \\
\text { (y1) }\end{array}$ & 0.474 & 0.480 & 0.074 & 6.377 & 0.000 \\
\hline $\begin{array}{l}\text { Training (x2) -> } \\
\text { Employee Performance (y2) }\end{array}$ & 0.321 & 0.319 & 0.058 & 5.490 & 0.000 \\
\hline $\begin{array}{l}\text { Organizational Commitment } \\
\text { (y1) -> Employee Performance } \\
\text { (y2) }\end{array}$ & 0.523 & 0.519 & 0.063 & 8.337 & 0.000 \\
\hline
\end{tabular}

Source: Smart PLS versi 3.2.8

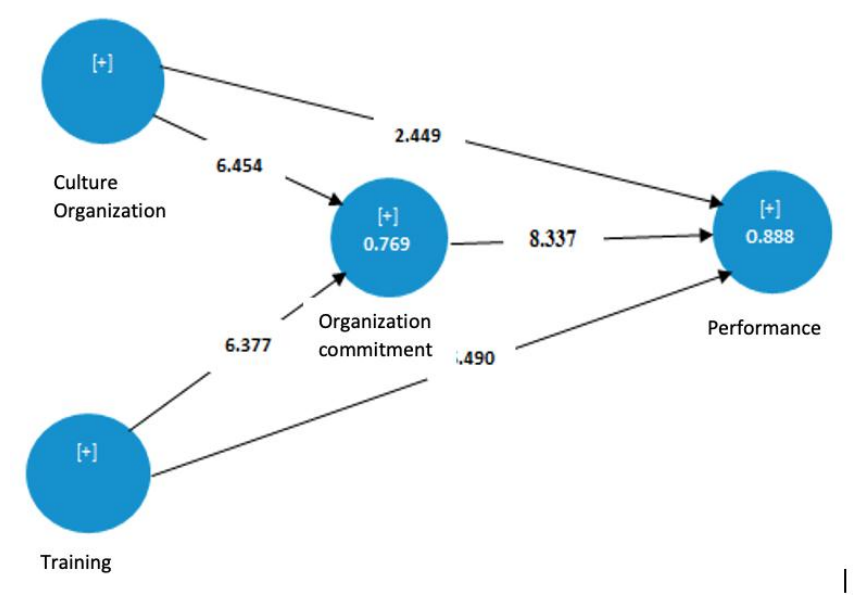

Figure 6. Bootstrapping Inner Model Calculation Result (Source: Smart PLS versi 3.2.8)

The research structural equation based on Figure 6 is:

Organizational Commitment $(\mathrm{Y} 1)=0.458 \gamma 1+0.474$ r2

Performance $(\mathrm{Y} 2)=0.154 \gamma 3+0.321 \gamma 4+0.523 \gamma 5$

Based on Table 4.12 it can be concluded as follows: 
a. Organizational Culture has an influence of 0.458 on Organizational Commitment with a T-statistic value of 6.454 and a P-value of 0.000 .

b. Organizational Culture has an influence of 0.154 on performance with a T-statistic value of 2.449 and a P-Values of 0.015 .

c. Training has an effect of 0.474 on Organizational Commitment with a T-statistic value of 6,377 and $\mathrm{P}$-Values of 0,000 .

d. Training has an effect of 0.321 on performance with a T-statistic value of 5.490 and PValues of 0.000 .

e. Organizational Commitment contributed 0.523 to performance with a t-statistic value of 8.337 and P-Values of 0.000 .

\section{$\mathbf{R}^{2}$ Evaluation dan F Statistic Test}

The results showed the value of $\mathrm{R}$ squares of 0.769 in the Organizational Commitment variable and 0.888 in the Performance variable. The value of $\mathrm{R}$ squares indicates that the structural model is very good. The simultaneous correlation of Organizational Culture and Training variables to Organizational Commitment is done by calculating F / F statistics using the following formula:

$\mathrm{R}^{2}=0,769$ (Organization Commitment)

$\mathrm{F}_{\text {count }} 1=\frac{\frac{R^{2}}{\{(k-1)}}{1-R^{2} /(n-k)}$

$\mathrm{F}_{\text {count }} 1=\frac{\frac{0,769}{[4-1)}}{1-0,769 /(120-3)}$

$\mathrm{F}_{\text {count }} 1=0,385 / 0,001974$

$\mathrm{F}_{\text {count }} 1=194,748$

So, $F$ count 1 (Organizational Commitment Variable) is 194,748

The simultaneous correlation of the variables of Organizational Culture, Training and Organizational Commitment to Performance is carried out by calculating the F / F statistic using the following formula: $\mathrm{R}^{2}=0,888$ (Perfomance)

$\mathrm{F}_{\text {count }} 2=\frac{\frac{R^{2}}{\left(k^{2}-1\right)}}{1-R^{2} /(n-k)}$

$\mathrm{F}_{\text {count }} 2=\frac{\frac{0,888}{[4-1]}}{1-0,888 /(120-4)}$

$F_{\text {count }} 2=0,296 / 0.000965$

$F_{\text {count }} 2=305,376$

So $\mathrm{F}_{\text {hitung }} 2$ (Performance Variable) is 305,376 
Table $3: \mathbf{R}^{2}$ Evaluation and F Statistic Test

\begin{tabular}{|c|c|c|c|c|c|}
\hline & R square & $\begin{array}{c}\text { F } \\
\text { Statistic }\end{array}$ & $\begin{array}{c}\mathbf{F} \\
\text { Table } \\
\end{array}$ & Alpha & Result \\
\hline $\begin{array}{l}(\mathrm{BO}, \mathrm{PEL})-> \\
\mathrm{KO}\end{array}$ & 0.769 & 194.748 & 2.68 & 0.05 & $\begin{array}{c}\text { FCount }>\text { FTable } \\
\left(\mathrm{H}_{6} \text { accepted }\right)\end{array}$ \\
\hline $\begin{array}{lll}(\mathrm{BO}, & \text { PEL, KO }) & -> \\
\mathrm{KIN} & & \\
\end{array}$ & 0.888 & 305.376 & 2.68 & 0.05 & $\begin{array}{c}\text { FCount > FTable } \\
(\text { H7 accepted })\end{array}$ \\
\hline
\end{tabular}

Source: Smart PLS Versi 3.2.8

The results of the above calculations show that the value of $F_{\text {count }} 1$ in this study is $194,748>\mathrm{F}$ table (2.68) which proves that the variables of organizational culture, training simultaneously have a positive and significant effect on organizational commitment. While the value of $\mathrm{F}$ count 2 is $305,376>\mathrm{F}$ table (2.68), so that the variables of organizational culture, training and organizational commitment simultaneously have a positive and significant effect on performance.

\section{Indirect Effect}

In this study, an estimate of the indirect effect was carried out, namely the role of the organizational commitment variable in mediating the influence of organizational culture variables and training variables on performance variables described in Figure 7 as follows

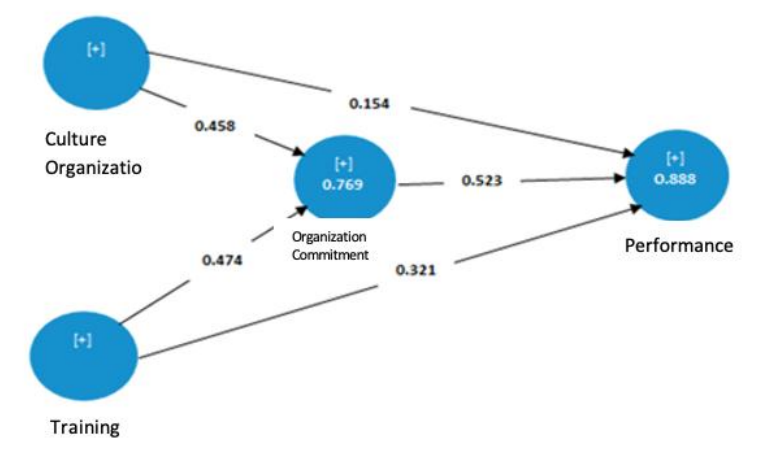

Figure 7. Indirect Effect Model Testing with Smart PLS

Figure 7. The value of the indirect effect of organizational culture and training on performance is as follows:

1) The indirect correlation of organizational culture on performance is the coefficient value of direct influence of organizational culture on organizational commitment multiplied by the coefficient value of direct influence of organizational commitment on performance $0.458 \times 0.523=0.239$.

2) The indirect correlation of training on performance, namely the coefficient value of the direct effect of training on organizational commitment multiplied by the coefficient value of direct influence of organizational commitment on performance $0.474 \times 0.523=0.247$.

\section{Inter dimension Correlation}

Correlation analysis between dimensions is to measure the level of relationship between dimensions in variable $\mathrm{X}$ with dimensions in variables $\mathrm{Y} 1$ and $\mathrm{Y} 2$ and dimensions in variable $\mathrm{Y} 1$ with dimensions in variable $\mathrm{Y} 2$. The results of the correlation between dimensions are shown in the table below: 
Table 4 : Results of Inter dimension correlation

\begin{tabular}{|c|c|c|c|c|c|c|}
\hline \multirow{3}{*}{ Variable } & \multirow{3}{*}{ Dimension } & \multicolumn{5}{|c|}{ Correlations } \\
\hline & & \multicolumn{3}{|c|}{ Organisation Commitment (Y1) } & \multicolumn{2}{|c|}{$\begin{array}{c}\text { Performance } \\
\text { Employee (Y2) }\end{array}$} \\
\hline & & Affective & Continuing & Normative & $\begin{array}{c}\text { Employee } \\
\text { Work } \\
\text { Goal } \\
\end{array}$ & $\begin{array}{c}\text { Behave } \\
\text { at } \\
\text { work }\end{array}$ \\
\hline \multirow{4}{*}{$\begin{array}{l}\text { Organizational } \\
\text { Culture (X1) }\end{array}$} & $\begin{array}{l}\text { Innovation and } \\
\text { Risk Thinking }\end{array}$ & 0.714 & 0.684 & 0.725 & 0.779 & 0.771 \\
\hline & $\begin{array}{l}\text { Attention to } \\
\text { details }\end{array}$ & 0.642 & 0.699 & 0.729 & 0.769 & 0.765 \\
\hline & $\begin{array}{l}\text { Result } \\
\text { orientation }\end{array}$ & 0.669 & 0.661 & 0.686 & 0.725 & 0.723 \\
\hline & $\begin{array}{l}\text { Individual } \\
\text { orientation }\end{array}$ & 0.786 & 0.811 & 0.856 & 0.814 & 0.809 \\
\hline \multirow{7}{*}{ Training (X2) } & $\begin{array}{l}\text { Team } \\
\text { orientation }\end{array}$ & 0.676 & 0.686 & 0.729 & 0.766 & 0.751 \\
\hline & Stability & 0.666 & 0.652 & 0.668 & 0.720 & 0.722 \\
\hline & Aggressiveness & 0.732 & 0.752 & 0.731 & 0.759 & 0.752 \\
\hline & Instructor & 0.693 & 0.741 & 0.759 & 0.853 & 0.838 \\
\hline & Participant & 0.673 & 0.728 & 0.821 & 0.882 & 0.800 \\
\hline & Material & 0.650 & 0.768 & 0.807 & 0.837 & 0.829 \\
\hline & Methods & 0.677 & 0.748 & 0.767 & 0.830 & 0.817 \\
\hline \multirow{4}{*}{$\begin{array}{l}\text { Organizational } \\
\text { Commitment } \\
\text { (Y1) }\end{array}$} & Aim & 0.612 & 0.716 & 0.757 & 0.796 & 0.781 \\
\hline & Affectiveness & - & - & - & 0.874 & 0.874 \\
\hline & Continuing & - & - & - & 0.848 & 0.853 \\
\hline & Normative & - & - & - & 0.879 & 0.872 \\
\hline
\end{tabular}

Source : Smart PLS Versi 3.2.8

Based on Table 4 above it can be concluded that the correlation between dimensions in this study is as follows:

1) In the organizational culture variable on the organizational commitment variable, the highest correlation dimension is the dimension of individual orientation to the normative dimension of 0.856 and is included in the very strong relationship level category. While the lowest dimensional correlation is the dimension of attention to detail on the affective dimension, which is 0.642 . So that the dimension of people orientation in organizational culture variables is needed in every increase in organizational commitment, especially in the normative dimension.

2) In the organizational culture variable on the performance variable, the highest correlation dimension is the dimension of people's orientation to the dimension of employee performance targets, amounting to 0.814 and is included in the very strong relationship level category. While the lowest correlation dimension is the dimension of stability to the dimension of employee performance targets of 0.720 . So that the dimension of people orientation in organizational culture variables is needed in every performance improvement, especially in the dimensions of employee performance targets.

3) In the training variable on the organizational commitment variable, the highest correlation dimension is the participant dimension to the normative dimension, which is 0.821 and is included in the very strong relationship level category. While the lowest dimensional correlation is the objective dimension to the affective dimension 
of 0.612. So that the participant dimension is needed in every increase in organizational commitment, especially in the normative dimension.

4) In the training variable on the performance variable, the highest correlation dimension is the participant dimension towards the employee work goal dimension, which is 0.882 and is included in the very strong relationship level category. While the lowest correlation dimension is stability dimension to the employee work plan dimension of 0.720. This explains that the dimensions of participants in training are needed in any performance improvement, especially in the dimensions of employee performance targets.

5) In the variable of organizational commitment to the performance variable, the highest correlation dimension is the normative dimension of the employee work goal dimension, amounting to 0.879 and is categorized as a very strong relationship level. While the lowest correlation dimension is the continuity dimension to the employee work plan dimension of 0.848 . So that the normative dimension in the organizational commitment variable is needed in any performance improvement, especially in the dimensions of employee performance targets.

\section{Discussion}

(1) Hypothesis 1 - Organizational Culture has a significant correlation on Organizational Commitment.

Obtained a path coefficient of 0.458 and t count (6.454)> t Table (1.98) with p of 0.000 , so that $\mathrm{H} 1$ is accepted $(\mathrm{p}<0.05)$ and $\mathrm{H} 0$ is rejected, organizational culture has a significant positive effect on organizational commitment. This result is in accordance with Patra research (2018).

(2) Hypothesis 2 - Training has a significant correlation on Organizational Commitment Obtained a path coefficient of 0.474 and $t$ count (6.377) $>t$ Table (1.98) with p of 0.000 , so that $\mathrm{H} 2$ is accepted ( $\mathrm{p}<0.05)$ and $\mathrm{H} 0$ is rejected, training has a significant positive effect on organizational commitment. This result is in accordance with Nugraha research (2017).

(3) Hypothesis 3 - Organizational Culture has a significant correlation on Performance Obtained a path coefficient of 0.154 and $t$ count (2.449)> t Table (1.98) with p of 0.015 , so that $\mathrm{H} 3$ is accepted $(\mathrm{p}<0.05)$ and $\mathrm{H} 0$ is rejected, organizational culture has a significant positive effect on performance. This result is in accordance with Wahyuni research (2015).

(4) Hypothesis 4 - Training has a significant correlation on performance

Obtained a path coefficient of 0.321 and $t$ count (5.490)> t Table (1.98) with $p$ of 0.000 , so that $\mathrm{H} 4$ is accepted $(\mathrm{p}<0.05)$ and $\mathrm{H} 0$ is rejected, training has a significant positive effect on performance. This result is in accordance with Riyanto, et.al research (2015).

(5) Hypothesis 5 - Organizational Commitment has a significant correlation on Performance

Obtained a path coefficient of 0.523 and t count (8.337)> t Table (1.98) with p of 0.000 , so that $\mathrm{H} 5$ is accepted $(\mathrm{p}<0.05)$ and $\mathrm{H} 0$ is rejected, organizational commitment has a significant positive correlation to performance. This result is in accordance with Sakti research (2015). 
(6) Hypothesis 6 - Organizational Culture and Training simultaneously has a significant correlation on Organizational Commitment.

The variable of Organizational Culture and Training has (R2) of 0.769 with a statistical F value of 194.748 and an $F$ table value at alpha 0.05 which is 2.68 . So that $F$ count $(194,748)>$ F Table (2.68), then H6 is accepted and H0 is rejected. Hypothesis 6 shows that the variables of organizational culture and training simultaneously have a positive and significant correlation to organizational commitment.

(7) Hypothesis 7 - Organizational Culture, Training, Organizational Commitment simultaneously has a significant correlation to performance

The variables of organizational culture, training and organizational commitment have (R2) of 0.888 with a statistical $F$ value of 305.376 and an $F$ table value at alpha 0.05 which is 2.68. So that F count $(305,376)>$ F Table (2.68), then H7 is accepted and H0 is rejected. Hypothesis 7 shows that the variables of organizational culture, training and organizational commitment simultaneously have a positive and significant correlation to performance.

(8) Hypothesis 8 - Organizational Commitment Mediates Organizational Culture and Training on Performance.

The path coefficient value of the direct influence of organizational culture on performance is 0.1542 < the path coefficient value of the indirect influence of organizational culture on performance is 0.239 and the $p$ value of the indirect effect of organizational culture on performance by mediating the organizational commitment variable is 0.000 with a t value of 5.099. The path coefficient value of the direct effect of training on performance is $0.3212<$ the coefficient value of the indirect effect of training on performance is 0.247 and the $\mathrm{p}$ value of the indirect effect of training variables on performance is mediated by the organizational commitment variable of 0.000 with a $t$ value of 5,293 . So that the $\mathrm{p}$ value obtained is $<0.05$ and t statistic $>1.98$, then $\mathrm{H} 0$ is rejected and $\mathrm{H} 8$ is accepted.

\section{CONCLUSION AND SUGGESTIONS}

1) Organizational culture has a significant positive effect on organizational commitment, with the strongest influence being the dimension of individual orientation

2) Training has a significant positive effect on organizational commitment, with the strongest influence being the participant dimension.

3) Organizational culture has a significant positive effect on performance, with the strongest influence being the dimension of individual orientation.

4) Training has a significant positive correlation to performance, with the strongest influence being the participant dimension.

5) Organizational commitment as a mediator has a significant correlation to performance.

6) Organizational culture and training simultaneously have a significant positive correlation to organizational commitment.

7) Organizational culture, training and organizational commitment simultaneously have a positive and significant correlation to performance.

8) Organizational commitment to mediate organizational culture and training on performance. 


\section{Suggestions}

1) The dimension of "individual orientation" in the organizational culture variable with the highest correlation is the dimension of "employee work plan" in the performance variable. So that these two dimensions must be the main concern in improving the performance of health worker staff at the Johar Baru Puskesmas. In the management aspect, performance targets must be well programmed in terms of quality and quantity by considering "people" as executors of activities. In making decisions, the leadership should coordinate all ideas and constructive opinions.

2) Ideally, employee performance targets should be adjusted to a training program preceded by a good selection of participants and on target.

3) The performance of health worker should be improved, so that organizational commitment as an important determinant of aspects of loyalty, moral obligation, involvement and various benefits can be received by employees.

4) Concretely the author suggests the following:

a) Puskesmas leaders should take part in leadership training on an ongoing basis with the aim of increasing organizational commitment and fostering employee responsibility in better carrying out work responsibilities.

b) There is a need for a capacity building program to motivate puskesmas employees so that they are committed, have a sense of full responsibility and have a strong mentality in facing the workload of the work place.

c) Internalization of puskesmas values, especially professional values, which are passed down into the work culture of employees so that employees will be accustomed to jobs with high professional demands, thus creating a good organizational culture.

d) It is necessary to have a routine motivation program for employees with the aim of fostering a high spirit of work culture for employees.

e) Puskesmas leaders should carefully select training participants so that training activities are right on target according to the job description and competencies related to the type of training.

f) The leadership evaluates the number of jobs, the weight of the work produced and the accuracy of the work results of employees at the Johar Baru District Health Center.

g) Leaders provide rewards for employees who perform well or very well so that employee work targets are maintained and increased and becoming a driving force for employees with poor performance results.

h) Leaders give punishment to employees who perform less well after coaching so as to increase the quantity, quality and accuracy of better work results completion.

\section{REFFERENCES}

[1] Aima Havidz, Adam Rizki, Ali Hapzi (2017). Model of Employee Performance: Competence Analysis and Motivation (Case Study at PT Bank Bukopin, Tbk Center. Journal of Research in Businness and Management. Vol.4, No 11

[2] Allen and Meyer. (2011). The Measurement and Antecedents of Affective, Contintinuance and NormativeCommitment to Organitazion. PT Elex Media Komputindo, Jakarta

[3] Arikunto, Suharsimi. (2013). Prosedur Penelitian Suatu Pendekatan Praktik. Rineka Cipta. Jakarta: Bangun. 
[4] Elmi, Farida. (2018). Telisik Manajemen Sumber Daya Manusia. Jakarta: Mitra Wacana Media.

[5] Fahmi, Irham. (2016). Pengantar Manajemen Sumber Daya Manusia Konsep dan Kinerja. Jakarta: Mitra Wacana Media.

[6] Kasmir. (2016). Manajemen Sumber Daya Manusia. Edisi 1.Cetakan 2: PT. Raja Grafindo Persada.

[7] Kharis, Indra (2015). Pengaruh Gaya Kepemimpinan Transformasional Terhadap Kinerja Karyawan Dengan Motivasi Kerja Sebagai Variabel Intervening. Jurnal Administrasi Bisnis (JAB) Vol. 3 No. 1. Universitas Brawijaya Malang.

[8] Lestari, Sri (2016). Pengukuran Kinerja dengan Pendekatan Balanced Scorered. Yogyakarta : UNY.

[9] Mangkunegara. Prabu. (2011). Evaluasi Sumber Daya Manusia. Bandung: PT. Refika Aditama.

[10] Mangkunegara, Prabu. (2015). Manajemen Sumber Daya Manusia Perusahaan. Bandung: PT. Remaja Rosda Karya.

[11] Nugraha, Reza Septian, Margono Setiawan, Astrid Puspaningrum. (2017). Komitmen Organisasional sebagai Mediasi Pengaruh Pelatihan dan Disiplin Kerja Terhadap Kinerja Pegawai (Studi pada Dinas Pendapatan Pengelolaan Keuangan dan Asset Kabupaten Malang). Jurnal Bisnis dan Manajemen Vol. 4 No.1, Januari 2017

[12] Patra, Anggi dan M. Havidz Aima (2018). The Effect of Organizational Culture and Job Satisfaction on Organizational Commitments and the Implementation on Organizational Citizenship Behavior in Employee of PT. Bali Towerindo Sentra Tbk. International Journal of Scientific and Research Publication, Vol. 8, Issue 12. ISSN 2250-3153. DOI: 10.29322/IJSRP.8.12.2018.p8443.

[13] Peraturan Pemerintah Republik Indonesia Nomor 46 Tahun 2011 Tentang Penilaian Prestasi Kerja Pegawai Negeri Sipil.

[14] Ricardianto, Prasadja. (2018). Human Capital Management: PT. IN MEDIA.

[15] Riyanto, Setyo, Ria Rahma Yanti, Hapzi Ali. (2017). The Effect of Training and Organizational Commitment on Performance of State University of Jakarta Student Cooperative (KOPMA UNJ) Management. Saudi Journal of Humanities and Social Sciences. ISSN 2415-6256. DOI: 10.21276/sjhss.

[16] Robbins., Coulter. (2010). Manajemen. Jilid 1.Edisi 10: PT. Gelora Aksara Pratama.

[17] Robbins, Stephen P \& Judge, Timothy A. (2013). Organizational Behavior Edition 15. New Jersey: Pearson Education.

[18] Sakti, Baskoro Kurnia. (2016). Pengaruh Kompensasi, Pelatihan dan Komitmen Organisasi Terhadap Kinerja Karyawan pada SPBU di Boja. Faculty of Economy \& Business. DINUS University.

[19] Sinambella, Poltak. (2018). Manajemen Sumber Daya Manusia. Cetakan 3: PT Bumi Aksara.

[20] Sugiyono. (2013). Metode Penelitian Kuantitatif, Kualitatif dan R\&D. Bandung: CV. Alfabeta.

[21] Swanson, E (2013). Nursing Outcomes Classification (NOC). United Kingdom : Moco Media.

[22] Undang-Undang Republik Indonesia Nomor 13/2003 tentang Ketenagakerjaan.

[23] Wahyuni, Evi. (2015). Pengaruh Budaya Organisasi dan Gaya Kepemimpinan Terhadap Kinerja Pegawai Bagian Keuangan Organisasi Sektor Publik Dengan Motivasi Kerja Sebagai Variabel Intervening (Studi Kasus pada Pegawai Pemerintah Kota Tasikmalaya). Jurnal Nominal, Vol. IV, No.1.

[24] Wibowo. (2017). Manajemen Kinerja. Jakarta: PT. Raja Grafindo Persada. 